УДК 327

DOI dx.doi.org/10.30970/vir.2018.44.0.9445

\title{
ZNACZENIE REPUBLIKI BIALORUSI W SYSTEMIE BEZPIECZEŃSTWA ŚWIATOWEGO
}

\author{
Aleksandra Koziol \\ Uniwersytet Jagielloński w Krakowie, \\ ul. Gotębia 24, Kraków, Polska, 31-007, +48- 1266310 46, \\ e-mail: aleks.koziol@student.uj.edu.pl
}

Republika Białorusi to państwo, które poprzez swoje położenie pomiędzy Federacją Rosyjską (FR) a państwami-członkami Unii Europejskiej (UE) i NATO, odgrywa istotną rolę w systemie bezpieczeństwa $\mathrm{w}$ regionie. $\mathrm{Z}$ jednej strony jest powiązane szeregiem zależności z władzami na Kremlu, z drugiej stara się równoważyć wpływy większego sąsiada kolejnymi ukłonami w stronę Zachodu. W związku z tym, bliższe przyjrzenie się znaczeniu Białorusi w europejskim systemie bezpieczeństwa wydaje się niezwykle istotne, szczególnie jeśli weźmiemy pod uwagę obecną sytuację międzynarodową - aneksję Krymu oraz konflikt na wschodzie Ukrainy, a także system sankcji nałożonych na FR w skutek niniejszych wydarzeń Przytoczone przykłady jasno wskazują na kierunek działań rosyjskich władz, coraz silniej broniących własnych interesów na obszarze postradzieckim. Interwencje tego typu nie mogą pozostać bez wpływu na politykę bezpieczeństwa Białorusi.

Celem niniejszego artykułu jest określenie roli i miejsca Republiki Białorusi w systemie bezpieczeństwa światowego. Badanie przeprowadzone zostało w oparciu o teorię Barrego Buzana, która wiąże ze sobą kwestie bezpieczeństwa narodowego i międzynarodowego, zwracając jednocześnie uwage na szereg współzależności, wynikajacych $\mathrm{z}$ procesu globalizacji. Analizie poddano więc zarówno wewnętrzne uwarunkowania białoruskiej polityki bezpieczeństwa, jak też kwestie międzynarodowe, w tym rolę aktorów państwowych oraz niepaństwowych, mających bezpośrednie przełożenie na kształtowanie systemu bezpieczeństwa światowego. Zastosowaną metodą badawczą jest metoda analizy systemowej w jej ujęciu makro, pozwalająca na przedstawienie systemu bezpieczeństwa światowego jako szeregu oddzielnych, acz ściśle powiązanych ze sobą elementów, dodatkowo wsparta metodą ilościową w odniesieniu do uwarunkowań systemu bezpieczeństwa.

W wyniku przeprowadzonych badań znaczenie Republiki Białorusi w systemie bezpieczeństwa światowego uznane zostało za istotne, głównie ze względu na położenie geopolityczne tego państwa. Niniejsza teza sformułowana została $\mathrm{w}$ oparciu o szereg czynników, z których najważniejsze to: 1) pozostawanie Białorusi w rosyjskiej strefie wpływów, której utrzymania władze w Moskwie nie boją się okupić licznymi kryzysami na arenie międzynarodowej (przypadek Ukrainy); 2) wysoki poziom integracji obu tych państw w zakresie polityki bezpieczeństwa; 3) kluczowe znaczenie retoryki i decyzji politycznych władz w Mińsku, mogących znaleźć przełożenie nie tylko na kształtowanie polityki tego konkretnego państwa, ale również na kształt bezpieczeństwa w Europie. Na obecnym etapie trudno jednak mówić o chęci integracji Białorusi ze strukturami zachodnimi, gdyż krok ten wymagałby przede wszystkim znaczących zmian wewnętrznych, na które reżim Aleksandra Łukaszenki nie jest gotów. W związku z powyższym prawdopodobne jest pozostanie Białorusi w aliansie z Federacją Rosyjską i dalsze zacieśnianie współpracy między oboma państwami.

Slowa kluczowe: Republika Białorusi; Federacja Rosyjska; NATO; Ukraina; bezpieczeństwo; uzbrojenie.

(C) Kozioł Aleksandra, 2018 
Wstęp

Republika Białorusi to państwo nie bez przyczyny określone przez Arkadego Moshesa w jednym z artykułów mianem «ziemi pomiędzy» [8]. Położone pomiędzy Federacją Rosyjską (FR) a państwami-członkami Unii Europejskiej (UE) i NATO, odgrywa istotną rolę $\mathrm{w}$ systemie bezpieczeństwa $\mathrm{w}$ regionie. $\mathrm{Z}$ jednej strony jest powiązane szeregiem zależności $\mathrm{z}$ władzami na Kremlu, $\mathrm{z}$ drugiej stara się równoważyć wpływy większego sąsiada kolejnymi ukłonami w stronę Zachodu. Choć w krótkiej perspektywie sytuacja polityczna na Białorusi wydaje się być stabilna, podobnie jak władza prezydenta Aleksandra Łukaszenki, nie należy jednak zapominać, że w perspektywie długookresowej może dojść w tym kraju do zmian, bądź zmierzających w kierunku zacieśnienia współpracy z FR, bądź też skłaniających do zawiązania dobrosąsiedzkich relacji z państwami UE i NATO. Bliższe przyjrzenie się znaczeniu Białorusi w europejskim systemie bezpieczeństwa staje się zaś szczególnie istotne, jeśli weźmiemy pod uwagę aneksję Krymu oraz konflikt na wschodzie Ukrainy, a także system sankcji nałożonych na FR w skutek niniejszych wydarzeń. Przytoczone przykłady jasno wskazują na kierunek działań rosyjskich władz, coraz silniej broniących własnych interesów na obszarze postradzieckim. Interwencje tego typu nie moga pozostać bez wpływu na politykę bezpieczeństwa Białorusi.

Celem niniejszego artykułu jest określenie roli i miejsca Białorusi w systemie bezpieczeństwa światowego. Badanie przeprowadzone zostało w oparciu o teorię Barrego Buzana, według której nie można już mówić o kwestiach bezpieczeństwa narodowego, nie wiążąc ich z bezpieczeństwem międzynarodowym. W związku z tym uwagę zwrócono na szereg współzależności, związanych z procesem globalizacji (w tym kwestie społeczne, polityczne i gospodarcze), a analizie poddano zarówno wewnętrzne uwarunkowania białoruskiej polityki bezpieczeństwa, jak też kwestie międzynarodowe, w tym rolę aktorów państwowych oraz niepaństwowych, mających bezpośrednie przełożenie na kształtowanie systemu bezpieczeństwa światowego [3]. Zastosowaną metodą badawczą jest zatem metoda analizy systemowej w jej ujęciu makro, pozwalająca ująć system bezpieczeństwa światowego jako szereg oddzielnych, acz ściśle powiązanych ze sobą elementów, dodatkowo wsparta metodą ilościową w odniesieniu do uwarunkowań systemu bezpieczeństwa oraz analizą treści $w$ odniesieniu do dokumentów [4, s. 45-46, 49].

\section{Uwarunkowania polityki bezpieczeństwa Republiki Białorusi}

Znaczenie Republiki Białorusi w systemie bezpieczeństwa światowego związane jest przede wszystkim z położeniem geograficznym tego państwa. W obecnej sytuacji geopolitycznej wydaje się to kluczowe, gdyż lokuje Białoruś pomiędzy dwoma strefami wpływów - zachodnią, reprezentowaną przez UE i NATO z jednej strony, rosyjską zaś $\mathrm{z}$ drugiej. Istotę problemu związanego $\mathrm{z}$ położeniem «pomiędzy» najlepiej potwierdza obecna sytuacja Ukrainy, którą pod wieloma względami do niedawna przyrównywano do Białorusi. Rewolucja z 2014 roku, która posłużyła dla władz w Moskwie jako pretekst do aneksji Krymu oraz wywołania konfliktu zbrojnego na obszarze Doniecka i Ługańska, obnażyła nie tylko wagę obszaru postradzieckiego w polityce bezpieczeństwa Federacji Rosyjskiej, ale unaoczniła 
także tragiczne konsekwencje, jakie niesie ze sobą konflikt interesów pomiędzy FR a Zachodem [5].

Podstawą w zakresie polityki bezpieczeństwa Białorusi jest Koncepcja bezpieczeństwa z 2010 roku [31] i Doktryna wojenna z 2016 roku [21]. Czas uchwalenia najnowszej wersji ostatniego dokumentu nie jest przypadkowy i można go traktować jako bezpośrednią odpowiedź na zmieniającą się sytuację polityczną i bezpieczeństwa w Europie Wschodniej. Jako istotne zagrożenie w Doktrynie wymienione zostały próby rewizji istniejącego porządku międzynarodowego, wojna hybrydowa i informacyjna, co pozostaje nie bez związku z agresją Federacji Rosyjskiej na Ukrainę. Nie zmienia to jednak faktu, że zarówno w Koncepcji, jak i Doktrynie jako główny sojusznik Białorusi wciąż wymieniana jest FR oraz potrzeba dążenia do wzmocnienia integracji wojskowej między oboma państwami. Tym niemniej, oba dokumenty za największe potencjalne zagrożenie dla bezpieczeństwa państwa uznają 1) ingerencje $\mathrm{w}$ niezawisłość i integralność terytorialną, a także 2) narzucanie kursu politycznego, niezgodnego z interesami państwa oraz ingerencję zewnętrzną w wewnątrzpolityczne procesy [31].

Potrzeba sojuszu z Federacją Rosyjską nie powinna dziwić, szczególnie jeśli weźmiemy pod uwagę silne związki między państwami, jakie ukształtowały się w procesie historycznym. Znajdują one odzwierciedlenie już w Konstytucji RB, w której $\mathrm{w}$ art. 17 rosyjski wymienia się na równi z białoruskim jako języki państwowe, sam zaś dokument sporządzony jest $\mathrm{w}$ języku rosyjskim, a na portalu Państwowego Centrum Informacji Prawnej, na którym jest zamieszczony, nie ma jego białoruskojęzycznej wersji [30]. Fakt ten stanowi podstawę do szerszych białoruskorosyjskich relacji, opartych o dominację języka rosyjskiego $\mathrm{w}$ dyskursie nie tylko politycznym, ale też edukacyjnym, prasowym czy wreszcie społecznym. Podobną tendencję uwidacznia spis powszechny, przeprowadzony w 2009 roku. Na pytanie o narodowość i język, jakiego zwykle używa się do rozmów w domu z 7,9 mln osób narodowości białoruskiej jedynie 2 mln zadeklarowało język białoruski, podczas gdy 5,5 mln wskazało język rosyjski [32].

Mimo deklaracji, zawartej $\mathrm{w}$ art. 18 Konstytucji, mówiącej o neutralności Białorusi [30], decyzje władz państwowych o silnej integracji z Federacją Rosyjską należy odbierać nie tylko jako efekt położenia geograficznego czy pewnej tradycji historycznej, ale wynik kalkulacji politycznej. Od UE Białoruś izoluje system polityczny, określany często mianem ostatniej dyktatury w Europie, co związane jest bezpośrednio $\mathrm{z}$ takimi kwestiami jak więźniowie polityczni oraz problemy $\mathrm{z}$ funkcjonowaniem niezależnych organizacji pozarządowych, partii czy mediów. Władze rosyjskie tymczasem, aby zachować wpływy na Białorusi jako części tzw. bliskiej zagranicy, tolerują reżim Aleksandra Łukaszenki. Dzięki temu (i wielu podobnym działaniom na innych frontach) buduja swoje geopolityczne zaplecze $\mathrm{w}$ kontrze do Zachodu i zapewniają FR status mocarstwa.

Jeśli zaś wziąć pod uwagę stosunkowo niską pozycję Białorusi na arenie międzynarodowej, konieczność zawierania aliansów z silniejszymi graczami leży w żywotnym interesie władz w Mińsku. Podobne stwierdzenie znajduje się zresztą w Koncepcji, definiującej trudność w kształtowaniu samodzielnej polityki zagranicznej 
Aleksandra Kozioł

ISSN 2078-4333. Вісник Львівського університету. Серія міжнародні відносини. 2018. Випуск 44

jako skutek obecnej sytuacji międzynarodowej. Dokument ten porusza także kwestie zapewnienia wojskowego bezpieczeństwa Białorusi, które w zadowalającym stopniu gwarantowane są poprzez polityczno-dyplomatyczne, informacyjne i inne niewojskowe środki [31].

Uwzględniając jednak wydatki na cele wojskowe, w 2017 roku Białoruś przeznaczyła na ten cel równowartość 631 mld dol., czyli 1,2 proc. PKB [14], białoruskie siły zbrojne liczą natomiast 46,4 tys. żołnierzy [22]. Dysproporcja potencjałów rysuje się wyraźnie, jeśli zestawić powyższe dane ze statystyką dotycząca trzech największych sąsiadów Białorusi - Rzeczpospolitej Polskiej, Ukrainy i FR. W tym samym roku Polska przeznaczyła na cele wojskowe 10 mld dol., zaś jej siły zbrojne liczą 110 tys. żołnierzy zawodowych [10]; Ukraina wydała 3,6 mld dol., podczas gdy liczba żołnierzy wynosi 204 tys. [27]; FR rozdysponowała 66,3 mld dol. [14], a w samym tylko Zachodnim Okręgu Wojskowym służy ponad 400 tys. żołnierzy (czyli ok. 40 proc. ogółu) [29], natomiast w całej FR liczba żołnierzy sięga nieco ponad $1 \mathrm{mln}$ [47].

Tab. 1: Wydatki wojskowe wybranych państw, w mln USD według aktualnych cen i kursów wymiany, 2017.

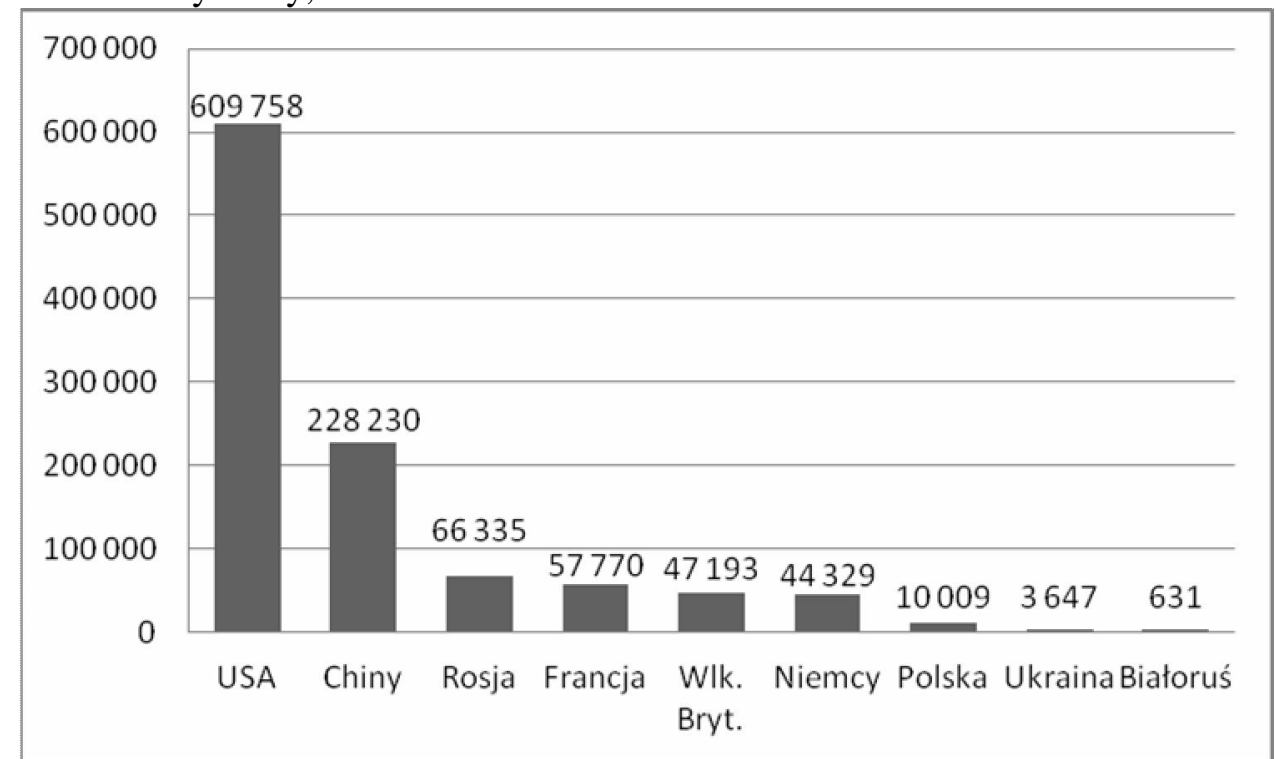

Źródło: Oprac. własne na podstawie SIPRI Military Expenditure Database.

Aby lepiej umiejscowić Białoruś w systemie bezpieczeństwa światowego, warto zwrócić także uwagę na ranking Global Firepower. W opracowaniu tym w 2018 roku zindeksowano 136 państw według ich siły, biorąc za podstawę do obliczeń 55 niezależnych czynników. Również w tym zestawieniu Białoruś zajęła stosunkowo niską lokatę, odstając także na tle takich państw jak Polska czy Ukraina, nie wspominając o europejskich czy światowych mocarstwach [1].

Tab. 2: Indeks siły (wartość idealna - 0,0000) oraz pozycja wybranych państw w rankingu Global Firepower. 


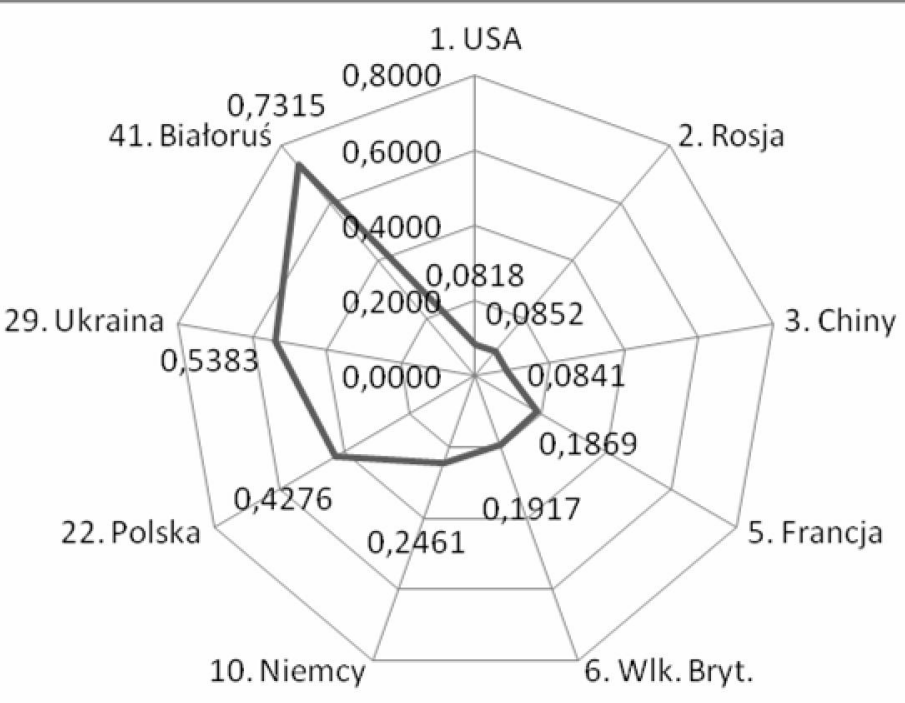

Źródło: Oprac. własne na podstawie 2018 Military Strength Ranking.

Jako podstawę przyjmując zaprezentowane powyżej dane i statystyki można stwierdzić, że samodzielna obrona kraju przez Siły Zbrojne Białorusi byłaby jeśli nie niemożliwa, to znacząco utrudniona, szczególnie, gdyby do ataku miało dojść z kierunku wschodniego. Białoruski system obrony skorelowany jest bowiem $\mathrm{z}$ rosyjskim i skierowany wyłącznie w kierunku zachodnim, a kraj podzielony jest na dwa Dowództwa Operacyjne: 1) Zachód, ze sztabem w Grodnie [28], i 2) PółnocZachód, ze sztabem w Borysowie [41]. Dodatkowym niesprzyjającym czynnikiem są także braki sprzętu bojowego oraz silne uzależnienie od ich dostaw z FR [16], przy czym w rosyjskiej strukturze eksportu Białoruś plasuje się na pozycji średniej wielkości odbiorcy [15]. Podobny rodzaj zagrożeń identyfikuje również Koncepcja bezpieczeństwa, w której jasno stwierdza się negatywne tendencje, związane ze starzeniem się uzbrojenia oraz pogarszaniem stanu infrastruktury wojskowej [31]. Dodatkowo należy uwzględnić traktowanie Białorusi jako bufora, pozwalającego w razie ewentualnego konfliktu z Zachodem (Białoruś bezpośrednio graniczy bowiem z państwami NATO) odsunąć linię obrony od rosyjskich granic nawet o $650 \mathrm{~km}$ [33], w czasie pokoju tymczasem alians militarny gwarantuje Rosjanom zabezpieczenie 1283km odcinka granicy [23].

Wobec tego trudno uznać Białoruś za państwo niezależne w kwestii kształtowania swojej polityki zagranicznej i bezpieczeństwa. Sojusz z FR gwarantuje jednak względną stabilność i przewidywalność, stanowi także gwarant bezpieczeństwa Białorusi.

Republika Białorusi w systemie bezpieczeństwa Federacji Rosyjskiej

Jak wskazywano wyżej, Republika Białorusi ma silne podstawy do utrzymania aliansu wojskowego z Federacją Rosyjską. Potwierdza to też szereg dokumentów, stanowiących bazę współdziałania obu państw. Jako fundament obecnej współpracy 
Aleksandra Kozioł

ISSN 2078-4333. Вісник Львівського університету. Серія міжнародні відносини. 2018. Випуск 44

służy przede wszystkim Umowa o utworzeniu Państwa Zwiazkowego Rosji i Białorusi z 1999 roku [25], a także Umowa między Federacja Rosyjskq a Republikq Białorusi w sprawie wspótpracy wojskowej z 1997 roku [24]. Zgodnie z ostatnim dokumentem strony zobowiązują się do koordynacji polityki bezpieczeństwa oraz stopniowego zbliżania i unifikacji prawodawstwa w tym zakresie, podejmują również decyzję o utworzeniu oraz koordynacji systemu zarządzania regionalnego zgrupowania wojsk. Niniejszy dokument stwarza ponadto możliwość wspólnego wykorzystania infrastruktury wojskowej oraz kształcenia kadr. Istotną rolę odgrywa także Porozumienie o wspólnej ochronie zewnętrznej granicy Państwa Zwiazkowego z 2009 roku, które weszło w życie trzy lata później, w 2012 roku. Uściśla ono reguły dotyczące wspólnego systemu ochrony zewnętrznej granicy PZ w przestrzeni powietrznej oraz ustanawia jednolity regionalny system obrony powietrznej [45]. Na tej podstawie jesienią 2013 roku nad białoruską przestrzenią powietrzną rozpoczęły dyżury rosyjskie myśliwce Su-27P, które stacjonują pod Baranowiczami [38]. W celu zwiększenia ochrony granicy PZ białoruskie i rosyjskie władze zdecydowały się także na podpisanie w 2016 roku Porozumienia w sprawie wspólnego zabezpieczenia technicznego regionalnego zgrupowania wojsk (sit), które porządkuje sposoby organizacji i współpracy Sił Zbrojnych Republiki Białorusi i Sił Zbrojnych Federacji Rosyjskiej w zakresie wspólnego wsparcia technicznego dla regionalnego zgrupowania wojsk, zapewniając jednocześnie, że odbywa się ono na podstawie wspólnej dyrektywy Sztabu Generalnego Sił Zbrojnych odpowiednio Federacji Rosyjskiej i Republiki Białorusi. W czasie zwiększonego zagrożenia lub wojny gwarantuje natomiast prawo Ministerstwu Obrony FR do dostarczania uzbrojenia i sprzętu wojskowego, a także innych materiałów białoruskiej części regionalnego ugrupowania wojsk. Ostatnie stwierdzenie jasno wskazuje na zdecydowaną przewagę militarną FR oraz uzależnienie Białorusi od rosyjskiego systemu obrony czy dostaw sprzętu [42]. W 2017 roku pojawiły się także doniesienia o pracach nad nową Doktryną wojenną Państwa Związkowego. Dokument nie został jednak jeszcze przyjęty, choć w prasie można napotkać liczne spekulacje na temat jego treści [46], a przedstawiciele władz obu państw podkreślają konieczność jego uchwalenia w związku ze zmieniającą się sytuacją międzynarodową, wskazując $m$. in. na rozmieszczanie wojsk NATO u granic PZ [36].

Współpraca Federacji Rosyjskiej z Republiką Białorusi opiera się, przede wszystkim, o pragmatyczny rachunek zysków i strat. Władze w Moskwie gotowe są ponosić szereg kosztów, związanych z utrzymaniem Białorusi w swojej strefie wpływów, ze względu na liczne korzyści, wynikające z tego faktu. Przede wszystkim należy tu wziąć pod uwagę potrzebę zachowania dominującej roli na obszarze postradzieckim i utrzymania statusu mocarstwa. Wszelkie instalacje wojskowe w państwach byłego ZSRR pozwalają bowiem zachować chociaż częściową kontrolę nad byłymi republikami i przesunąć na nie część kosztów zabezpieczenia granic FR. Białoruś wśród innych państw tego obszaru wyróżnia dodatkowo fakt granicy z państwami NATO. Na jej terytorium znajdują się także dwa obiekty wojskowe. Pierwszy to stacja radiolokacyjna Wilejka, zabezpieczająca łączność z podwodnymi okrętami atomowymi [43], drugi - węzeł Baranowicze, stanowiący część systemu 
wczesnego ostrzegania przed atakiem rakietowym i służący do monitoringu przestrzeni kosmicznej [44]. Często błędnie określane są mianem rosyjskich «baz wojskowych» - nie jest to jednak zgodne z prawdą. Informacja na ten temat znajduje się w zawartych między państwami porozumieniach, które jasno wskazują, że są to obiekty wojskowe, stanowiące białoruską własność (poza ruchomościami) i oddane są Rosjanom w bezpłatną dzierżawę na okres 25 lat, bez automatycznego przedłużenia. W 2013 roku pojawiła się jednak informacja o planowanym otwarciu bazy lotniczej na Białorusi (najprawdopodobniej w Bobrujsku) [19], a dwa lata później przygotowano nawet stosowny projekt umowy [34]. Ostatecznie do dyslokacji Su-27SM3 na Białorusi jednak nie doszło, gdyż FR postanowiła odtworzyć w Kaliningradzie 689. pułk lotnictwa i na ten cel przeznaczyć swoje myśliwce [19;37].

Co więcej, dla obu państw współpraca jest istotna ze względu na więzi, jakie ukształtowały się między ich przemysłami obronnymi. Na Białorusi produkowane są części uzbrojenia, dostarczane następnie do FR, Rosjanie natomiast oferują Białorusinom bezpłatne dostawy sprzętu wojskowego. Według danych SIPRI podobna transakcja miała dotyczyć na przykład wyprodukowanych na Białorusi platform mobilnych do rakietowych pocisków balistycznych Topol-M, w zamian za dostarczenie których strona rosyjska częściowo sfinansowała dostawę rakietowych systemów S-300 [17]. Mimo to należy pamiętać o dysproporcji potencjałów między oboma państwami i fakcie, że to jednak Rosjanie w znaczącym stopniu subsydiuja białoruski przemysł obronny [26;35].

Niemniej, oba państwa regularnie prowadzą wspólne ćwiczenia wojskowe, z których najważniejsze to «Zachód» i «Tarcza Związku» - odbywają się naprzemiennie co dwa lata i służą jako sprawdzian gotowości bojowej dla regionalnego zgrupowania wojsk [39]. Ponadto Białoruś i FR są członkami Organizacji Układu o Bezpieczeństwie Zbiorowym i w ramach tej organizacji również prowadzą wspólne ćwiczenia [48].

Oceniając efekty współpracy i integracji rosyjsko-białoruskiej w dziedzinie bezpieczeństwa i obronności, należy uznać, że jest ona bardzo zaawansowana i na tle politycznym czy gospodarczym wywołuje stosunkowo niewiele kontrowersji. Co więcej, prowadzenie samodzielnej polityki obronnej wymagałoby od Białorusi nakładów finansowych, te zaś FR jest gotowa ponosić ze względów strategicznych.

\section{Republika Bialorusi a kwestie bezpieczeństwa w Europie}

Można śmiało stwierdzić, że po aneksji Krymu oraz wybuchu konfliktu na wschodzie Ukrainy białoruskie władze po raz pierwszy od rozpadu ZSRR wyraźnie odczuły, jak silnie uzależnione są nie tylko od rosyjskiego wsparcia finansowego, ale faktycznie także od decyzji politycznych, jakie zapadają na Kremlu. Zaprezentowane powyżej dane jasno wskazują, że Białoruś nie byłaby w stanie przeciwstawić się FR w razie ewentualnego konfliktu, przez co tym bardziej uprawnione jest stwierdzenie, że reżim Aleksandra Łukaszenki stanowi jedynie element szerszej gry Rosjan $\mathrm{z}$ Zachodem. Mimo to, a także z powodu kryzysu w stosunkach FR z Ukraina, Republika Białorusi stała się jedynym partnerem władz w Moskwie na zachód od rosyjskich granic. W związku z tym można przypuszczać, iż traktując Białoruś jako strefę swoich uprzywilejowanych interesów, Rosjanie z pewnością nie dopuszczą do 
wyjścia tego państwa z ich strefy wpływów. Nie wydaje się jednak, by w obecnej sytuacji geopolitycznej oraz zaawansowanej współpracy z FR, białoruskie władze miały inną, realną alternatywę.

Współpraca z Zachodem wymagałaby bowiem poważnych zmian w systemie politycznym, na co obecny reżim nie wyraża zgody. Markowane są co prawda kolejne «gesty» Białorusi w kierunku UE i NATO, jednak noszą one charakter w dużej mierze symboliczny $[11 ; 9 ; 6]$. O ile jednak współpraca Białorusi z NATO, ze względu na sojusz militarny z FR, wydaje się utrzymać w najbliższej przyszłości na podobnym poziomie, o tyle w ostatnich dwóch latach zauważalna jest intensyfikacja działań na linii Białoruś-UE [7]. Co prawda białoruskie władze jako oficjalną przyczynę podobnych działań wskazują kryzys ekonomiczny, jednak wyraźna jest tu także zbieżność czasu, w jakim podjęto starania na rzecz dywersyfikacji białoruskiej polityki z wybuchem kryzysu w stosunkach rosyjsko-ukraińskich [13].

Podczas gdy szerszy zakres współpracy ze strukturami zachodnimi napotyka liczne przeszkody, dywersyfikacja polityki Białorusi oparła się w ostatnich latach również o innego partnera - Chińską Republikę Ludową. Współpraca z tym państwem gwarantuje bowiem przypływ kapitału (szczególnie chodzi tu o możliwość zaciagania pożyczek) i inwestycji, nie wiąże się jednak z koniecznością przeprowadzania reform wewnętrznych. Co więcej, ze względu na współpracę rosyjsko-chińską, nie budzi również większych obaw u władz w Moskwie [13;2]. Dzięki ChRL Białoruś zyskuje jednak częściową możliwość uniezależnienia od FR w zakresie modernizacji i produkcji uzbrojenia. Przykładem jest wieloprowadnicowy system rakietowy «Polonez», który od 2015 roku powstaje w białoruskich fabrykach przy chińskim wsparciu. Na Białorusi posłuży on jako zamiana dla postsowieckich zestawów BM-30 «Smiercz», jednak coraz głośniej mówi się także o jego potencjalnym eksporcie do Azerbejdżanu $[40 ; 12 ; 18]$.

Jak wynika z powyższych rozważań, nawet w ramach ograniczonych możliwości, władze Białoruskie zdają się w dość umiejętny sposób rozgrywać swoje położenie. Negocjują dla siebie możliwie korzystne warunki, także w zakresie bezpieczeństwa, starając się zarówno utrzymać sojusz wojskowy z FR, jak też przyciagając innych partnerów, dążąc do niewielkiej choćby dywersyfikacji kierunków współpracy.

\section{Podsumowanie}

Znaczenie Republiki Białorusi w systemie bezpieczeństwa światowego jest o tyle istotne, o ile weźmiemy pod uwagę jej położenie geopolityczne. Przede wszystkim należy wziąć pod uwagę fakt przynależności Białorusi do rosyjskiej strefy wpływów, a także poziom integracji obu tych państw w zakresie polityki bezpieczeństwa. Jak wnioskować można po ataku FR na Ukrainę, władze w Moskwie są w stanie w sposób ostry i zdecydowany bronić wpływów w regionie tzw. bliskiej zagranicy. I choć Białoruś zdaje się dotąd w ścisły sposób współpracować z FR, w jej interesie nie leży jednak pełne uzależnienie od wschodniego sąsiada. Mimo to, ze względu na obecny układ sił, Białoruś ma ograniczone możliwości kształtowania samodzielnej polityki. Wiąże się to jednak nie tylko z wysokim poziomem współpracy z FR w zakresie bezpieczeństwa (oraz polityki i gospodarki), ale także z niechęci reżimu Aleksandra 
Łukaszenki do przeprowadzania wewnętrznych zmian, które warunkują dalsze postępy we wspótpracy z UE czy NATO.

Mimo to, każda zmiana retoryki władz na Białorusi powinna być uważnie obserwowana. W dłuższej perspektywie może bowiem zadecydować nie tylko o wyborze politycznym tego konkretnego państwa, ale również o kształcie bezpieczeństwa w Europie. Na obecnym etapie można jedynie stwierdzić, że wzrost napięć w stosunkach na linii FR-NATO jest dla Białorusi wysoce niekorzystny, z jednej strony spycha ją bowiem w rosyjską orbitę wpływów, z drugiej natomiast odcina możliwości współpracy $\mathrm{z}$ zachodnimi partnerami. Dodatkowo podnosi również, w przypadku eskalacji konfliktu, bezpośrednie zagrożenie dla bezpieczeństwa tegoż państwa. W związku z powyższym postawić można tezę, iż mimo stosunkowo niewielkiego potencjału wojskowego Białorusi, państwo to odgrywa w tym momencie istotną rolę w systemie bezpieczeństwa światowego.

\section{BIBLIOGRAFIA}

1. 2018 Military Strength Ranking, Global Firepower, https://www.globalfirepower.com/countrieslisting.asp (28.05.2018).

2. Belarusian-Chinese Intergovernmental Committee on Cooperation, http://www.belaruschina.by/en (28.05.2018).

3. Buzan B., Waever O., Regions and Power. The Structure of International Security, Cambridge University Press: Cambridge 2003.

4. Chmaj M., Żmigrodzki M., Wprowadzenie do teorii polityki, Wyd. UMCS: Lublin 2001.

5. Datskova L., Possible Effects of the Ukrainian Revolution for Russia and Belarus - Modern Trends, «Nowy Prometeusz», t. 5, nr 7, 2015.

6. EU relations with Belarus, http://www.consilium.europa.eu/en/policies/eastern-partnership/ belarus/ (28.05.2018).

7. EU-Belarus relations, 01.11.2017, https://eeas.europa.eu/headquarters/headquarters-homepage_ en/35606/EU-Belarus\%20relations (28.05.2018).

8. Moshes A., BELARUS: Land Between, «The World Today», Vol. 66, No. 12 (December 2010), pp. 30-31, http://www.jstor.org/stable/41963038 (21.05.2018).

9. NATO supports Belarus on many security matters, «BelTA», 15.12.2017, http://eng.belta.by/ politics/view/nato-supports-belarus-on-many-security-matters-107736-2017/ (28.05.2018).

10. Podstawowe informacje o budżecie resortu obrony narodowej na $2018 \mathrm{r}$., Ministerstwo Obrony Narodowej, http://www.mon.gov.pl/d/pliki/dokumenty/rozne/2018/02/budzet2018.pdf (25.05.2018).

11. Relations with Belarus, https://www.nato.int/cps/en/natohq/topics_49119.htm?selectedLocale=en (28.05.2018).

12. Sabak J., Rakietowe «Polonezy» już na uzbrojeniu Białorusi. Zasieg: $200 \mathrm{~km}$, «Defence24», 23.08.2016, http://www.defence24.pl/rakietowe-polonezy-juz-na-uzbrojeniu-bialorusi-zasieg-200-km (28.05.2018).

13. Shotter J., Belarus performs balancing act in move to strengthen EU ties, «Financial Times», 24.10.2017, https://www.ft.com/content/a0ecd9c4-ac57-11e7-aab9-abaa44b1e130 (28.05.2018).

14. SIPRI Military Expenditure Database, https://www.sipri.org/databases/milex (24.05.2018).

15. TIV of arms exports from Russia, 1994-2017, SIPRI Arms Transfers Database, http://armstrade.sipri.org/armstrade/html/export_values.php (26.05.2018).

16. TIV of arms exports to Belarus, 1994-2017, SIPRI Arms Transfers Database, http://armstrade.sipri.org/armstrade/html/export_values.php (26.05.2018).

17. Transfers of major weapons: Deals with deliveries or orders made for 1994 to 2017, SIPRI Arms Transfers Database, http://armstrade.sipri.org/armstrade/page/trade_register.php (27.05.2018). 
Aleksandra Kozioł

ISSN 2078-4333. Вісник Львівського університету. Серія міжнародні відносини. 2018. Випуск 44

18. «Ђ»: Системы залпового огня «Полонез» Беларусь планирует поставлять в Азербайджан уже в 2018 году, «TUT.BY», 18.04.2018, https://news.tut.by/economics/589250.html?crnd=81318 (28.05.2018).

19. Алесин А., Вопрос российской авиабазы в Беларуси закрыт. Но у Москвы есть другие вопросы, «Белорусские новости», 16.01.2018, https://naviny.by/article/20180116/1516081802-voprosrossiyskoy-aviabazy-v-belarusi-zakryt-no-u-moskvy-est-drugie (27.05.2018).

20. В Минске состоялась встреча Министра обороны России с Президентом Белоруссии, 23.04.2013, http://mil.ru/conference_of_pro/news/more.htm?id=11729810@egNews (27.05.2018).

21. Военная доктрина Республики Беларусь, http://www.mil.by/ru/military_policy/doktrina/ (24.05.2018).

22. Вооружённые силь Республики Беларусь в настоящее время, Белорусская военная газета «Во славу Родины», 23.02.2018, https://vsr.mil.by/2018/02/23/vooruzhyonnye-sily-respubliki-belarus-vnastoyashhee-vremya/ (26.05.2018).

23. Государственный пограничный комитет Республики Беларусь, http:/gpk.gov.by/maps/ (26.05.2018).

24. Договор между Российской Федерачией и Республикой Беларусь о военном сотрудничестве, http://www.mid.ru/foreign_policy/international_contracts/2_contract/-/storage-viewer/ bilateral/page-257/47428 (27.05.2018).

25. Договор о создании Союзного государства, http://www.soyuz.by/about/docs/dogovor5/ (27.05.2018).

26. Заквасин А., Хлусова К., Союзное войско: чего достиг военный блок России и Белоруссии за 20 лет существования, «RT», 2.04.2017, https://russian.rt.com/ussr/article/374321-rossiyabelorussiya-voennoe-sotrudnichestvo (27.05.2018)

27. Закон України Про чисельність Збройних Сил України, http://zakon3.rada.gov.ua/laws/show/ $235-19(26.05 .2018)$

28. Западное оперативное командование, http://www.mil.by/ru/forces/sv/zok/ (26.05.2018).

29. Западный военный округ, Министерство обороны Российской Федерации, https://structure.mil.ru/structure/okruga/west/history.htm (26.05.2018).

30. Конституичия Республики Беларусь, http://pravo.by/pravovaya-informatsiya/normativnyedokumenty/konstitutsiya-respubliki-belarus/ (24.05.2018).

31. Концепџия начиональной безопасности Республики Беларусь, http://www.mil.by/ru/ military_policy/koncep/ (24.05.2018).

32. Население по начиональности и языку, на котором обычно разговаривает дома, Перепись населения Республики Беларусь 2009 года, http://www.belstat.gov.by/upload-belstat/upload-belstatpdf/perepis_2009/5.9-0.pdf (24.05.2018).

33. Основные факты, Официальный Интернет-портал Президента Республики Беларусь, http://president.gov.by/ru/facts-ru/ (26.05.2018).

34. Постановление от 7 сентября 2015 г. № 945 О представлении Президенту Российской Федерачии предложения о подписании Соглашения между Российской Федерачией и Республикой Беларусь о российской авиационной базе на территории Республики Беларусь, http://static.government.ru/media/files/pYnNuQ9AuAVXgssL8xq3

dNVUApeAeoE2.pdf (27.05.2018).

35. Программа «Совершенствование объектов военной инфраструктуры, планируемых к совместному использованию в интересах обеспечения региональной группировки войск (сил) Республики Беларусь и Российской Федерации» на 2017-2020 г2., https://www.postkomsg.com/ programs/208852/ (28.05.2018).

36. Проект военной доктрины Союзного государства согласуют в ближайшие месяцы, «TACC», 27.02.2018, http://tass.ru/mezhdunarodnaya-panorama/4991047 (27.05.2018).

37. Рамм А., Сурков Н., Дмитриев Е., Щит для Калининграда, «Известия», 11.01.2018, https://iz.ru/693779/aleksei-ramm-nikolai-surkov-evgenii-dmitriev/shchit-dlia-kaliningrada (27.05.2018).

38. Российские истребители «Су-27П» заступили на боевое дежурство на авиабазе в Барановичах, «TUT.BY», 10.21.2013, https://news.tut.by/society/378248.html?crnd=44140 (27.05.2018). 
39. Российско-белорусские учения «Запад» / «Щит Союза», «РИА Новости», 14.09.2017, https://ria.ru/spravka/20170914/1504679556.html (27.09.2018).

40. РСЗО «Полонез» поступила в Вооруженные Силы Беларуси, 22.08.2016, http://www.mil.by/ru/news/57183/ (28.05.2018).

41. Северо-западное оперативное командование, http://www.mil.by/ru/forces/sv/szok/ index.php (26.05.2018).

42. Соглашение между Правительством Российской Федерации и Правительством Республики Беларусь о совместном техническом обеспечении региональной группировки войск (сил) Российской Федераиии и Республики Беларусь, http://www.mid.ru/foreign_policy/ international_contracts/2_contract/-/storage-viewer/bilateral/page2/51724?_storageviewer_WAR_storage viewerportlet_advancedSearch=false\&_storageviewer_WAR_storageviewerportlet_keywords=\%D0\%B1 $\% \mathrm{D} 0 \% \mathrm{~B} 5 \% \mathrm{D} 0 \% \mathrm{BB} \% \mathrm{D} 0 \% \mathrm{~B} 0 \% \mathrm{D} 1 \% 80 \&$ \&storageviewer_WAR_storageviewerportlet_fromPage $=$ search \&_storageviewer_WAR_storageviewerportlet_andOperator=1 (27.05.2018).

43. Соглатение между Правительством Российской Федерации и Правительством Республики Беларусь о порядке использования и содержания радиостанции Вилейка, расположенной на территории Республики Беларусь, http://www.mid.ru/foreign_policy/ international_contracts/2_contract/-/storage-viewer/bilateral/page-291/48023 (27.05.2018).

44. Соглатение между Правительством Российской Федерачии и Правительством Республики Беларусь о порядке завершения строительства, использования и содержания Узла Барановичи системы предупреждения о ракетном нападении, расположенного на территории Республики Беларусь, http://www.mid.ru/foreign_policy/international_contracts/2_contract/-/storageviewer/bilateral/page-1/48024?_storageviewer_WAR_storageviewerportlet_advancedSearch=false\& storageviewer_WAR_storageviewerportlet_keywords=\%D0\%91\%D0\%B0\%D1\%80\%D0\%B0\%D0\%BD $\% \mathrm{D} 0 \% \mathrm{BE} \% \mathrm{D} 0 \% \mathrm{~B} 2 \% \mathrm{D} 0 \% \mathrm{~B} 8 \% \mathrm{D} 1 \% 87 \% \mathrm{D} 0 \% \mathrm{~B} 8$ \&_storageviewer_WAR_storageviewerportlet_fromPa $\mathrm{ge}=$ search\&_storageviewer_WAR_storageviewerportlet_andOperator=1 (27.05.2018).

45. Соглашение между Российской Федераџией и Республикой Беларусь о совместной охране внешней границь Союзного Государства в воздушном пространстве и создании единой региональной системы противовоздушной обороны Российской Федерации и Республики Беларусь, http://www.mid.ru/foreign_policy/international_contracts/2_contract/ -/storage-viewer/bilateral/page-101/45413 (27.09.2018)

46. Тиханский А., Новая военная доктрина Союзного государства Беларуси и России: «гибридные войныл» и «иветные революиии», «Евразия Эксперт», 27.12.2017, http://eurasia.expert/ novaya-voennaya-doktrina-soyuznogo-gosudarstva-belarusi-i-rossii-gibridnye-voyny-i-tsvetnyerevolyuts/ (27.05.2018).

47. Указ Президента Российской Федерации от 17.11.2017 г. № 555 Об установлении штатной численности Вооруженных Сил Российской Федеращии, http://www.kremlin.ru/ acts/bank/42477 (26.05.2018).

48. Учения Коллективных сил ОДКБ, http://www.odkb-csto.org/training/ (27.05.2018).

Стаття надійшла до редколегї 10.06.2018

Прийнята до друку 01.09.2018

\title{
ЗНАЧЕННЯ РЕСПУБЛІКИ БІЛОРУСЬ В СИСТЕМІ МІЖНАРОДНОЇ БЕЗПЕКИ
}

\author{
Александра Козьол \\ Ягеллонський університет в Кракові, \\ вул. Голебя, 24, м. Краків, Польща, 31-007, +48- 1266310 46, \\ e-mail: aleks.koziol@student.uj.edu.pl
}

Республіка Білорусь є державою, яка через своє розташування між Російською Федерацією (РФ) та державами-членами Європейського Союзу (ЄС) та НАТО відіграє важливу роль у системі безпеки в регіоні. 3 одного боку Білорусь пов'язана низкою відносин з владою Кремля, з іншого боку, намагається зрівноважити вплив великої сусідки на подальші випади в бік Заходу. Тому 
Aleksandra Kozioł

уважний погляд на важливість Білорусі в європейській системі безпеки видається надзвичайно важливий, особливо враховуючи нинішню міжнародну ситуацію - анексію Криму та конфлікт на Сході України, а також систему санкцій, введених стосовно Російської Федерації як наслідок цих подій. Наведені приклади чітко вказують на напрямки дій російської влади, які все більше захищають власні інтереси на пострадянському просторі. Втручання такого типу не можуть залишатися без впливу на політику безпеки Білорусі.

Метою даної статті є визначення ролі та місця Республіки Білорусь у системі глобальної безпеки. Дослідження проведено на основі теорії Баррі Бузана, яка пов'язує проблеми національної та міжнародної безпеки, приділяючи водночас увагу ряду взаємозалежностей, що випливають із процесу глобалізації. Тому були проаналізовані як внутрішні особливості білоруської політики безпеки, так і міжнародні проблеми, включаючи роль державних і недержавних суб'єктів, які безпосередньо впливають на формування глобальної системи безпеки. У досліджені використовується метод системного аналізу, який дає змогу представляти глобальну систему безпеки як сукупність окремих, але тісно пов'язаних елементів, із застосуванням кількісних методів стосовно умов системи безпеки.

У результаті проведених досліджень показано, що значення Республіки Білорусь у системі глобальної безпеки $є$ значним, насамперед через геополітичне розташування цієї країни. Такий висновок зроблено на основі ряду чинників, серед яких найважливішими $є: 1)$ знаходження Білорусі в сфері впливу Росії, за що московська влада не боїться платити чисельними кризами на міжнародній арені (приклад України); 2) високий рівень інтеграції обох цих країн у сфері політики безпеки; 3) ключове значення риторики уряду та політичних рішень у Мінську, які можуть бути перекладені не тільки на формування політики цієї конкретної країни, але також і на проблеми безпеки в Свропі. Проте на цьому етапі важко говорити про бажання інтегрувати Білорусь із західними структурами, оскільки цей крок насамперед вимагатиме значних внутрішніх змін, до яких режим Олександра Лукашенко не готовий. У зв'язку з вищесказаним, цілком імовірно, що Білорусь буде залишатися в союзі з Російською Федерацією з подальшим посиленням співпраці між двома країнами.

Ключові слова: Республіка Білорусь; Російська Федерація; НАТО; Україна; безпека; озброєння.

\title{
THE IMPORTANCE OF THE REPUBLIC OF BELARUS IN THE WORLD SECURITY SYSTEM
}

\author{
Aleksandra Koziol \\ Uniwersytet Jagielloński w Krakowie, \\ ul. Gotębia 24, Kraków, Poland, 31-007, +48- 1266310 46, \\ e-mail: aleks.koziol@student.uj.edu.pl
}

The Republic of Belarus is a state that, through its location between the Russian Federation (RF) and the members states of the European Union (EU) and NATO, plays an important role in the security system in the region. On the one hand, through a number of dependencies it is closely related to the Kremlin authorities, on the other hand it tries to balance the influence of the larger neighbor through some steps towards closer cooperation with the West. Therefore, a closer look at the importance of Belarus in the European security system seems to be extremely vital, especially considering the current international situation - the annexation of Crimea and the conflict in eastern Ukraine, as well as the system of sanctions imposed on the Russian Federation as a result of these events. The abovementioned examples clearly indicate the direction of actions of the Russian authorities, which are increasingly defending their own interests in the post-Soviet area. All those decisive actions, that were undertaken in order to prevent even the threat of losing influence, must certainly be important for Belarusian security policy.

The purpose of this article is to define the role and place of the Republic of Belarus in the global security system. The study was conducted on the basis of Barry Buzan's theory, which links issues of national and international security, while paying attention to a number of interdependencies resulting from the globalization process. Therefore, both the internal determinants of the Belarusian security policy 
and international issues were analyzed, including the role of state and non-state actors, having a direct impact on shaping the global security system. The applied research method is a method of system analysis in its macro approach, which allows the presentation of the global security system as a series of separate, but closely related elements, additionally supported by a quantitative method in relation to the security system's conditions.

As a result of the conducted research, the significance of the Republic of Belarus in the global security system was considered high, mainly due to the geopolitical location of that specific country. Following thesis was formulated on the basis of a number of factors, the most important of which are: 1) the remain of Belarus in the Russian sphere of influence, for which the Moscow authorities are not afraid to pay with numerous crises in the international arena (the case of Ukraine); 2) a high level of integration of both countries in the field of security policy; 3) the key significance of the government's rhetoric and political decisions in Minsk, relevant not only to the policy making of this particular country, but also to security in Europe. At this stage, however, it is difficult to talk about the Belarusian will to integrate with Western structures, because this step would, first of all, require significant internal changes, for which the regime of Alexander Lukashenko is not ready. In connection with the above, it is likely that Belarus will remain in alliance with the Russian Federation and that cooperation between the two countries will further tighten.

Key words: Republic of Belarus; Russian Federation; NATO; Ukraine; security; armament. 